\title{
THE HEPATIC BLOOD FLOW AND SPLANCHNIC OXYGEN CONSUMPTION IN ALCOHOLIC FATTY LIVER
}

\author{
BY BRUCE J. KESSLER, JOHN B. LIEBLER, GERALD J. BRONFIN, AND \\ MARTIN SASS \\ (From the Medical Service, Veterans Administration Hospital, Brooklyn, N. Y., and the De- \\ partment of Medicine, State University of Neww York, College of Medicine at \\ New York City)
}

(Submitted for publication May 13, 1954; accepted June 2, 1954)

Observations made during the development of choline-deficiency cirrhosis in animals have shown that fat accumulation precedes the appearance of fibrosis in the liver (1-3). Information obtained from autopsy and liver biopsy material (4-7) indicates that this probably also holds true for alcoholic cirrhosis in man. However, there is no agreement concerning the importance of the part which fat infiltration plays in the pathogenesis of either of these types of cirrhosis.

It has been suggested that compression of intralobular sinusoids by fat-distended liver cells impedes the intralobular circulation and that this, in part, contributes to the degeneration of centrilobular hepatic parenchyma (8). Evidence to support this hypothesis has been presented by Himsworth (8) and Hartroft (9), who studied sections of fatty livers from rats injected with India Ink prior to sacrifice. They demonstrated that in sections showing marked fat infiltration the penetration of sinusoids with ink was markedly limited as compared to the penetration of ink into the sinusoids of normal liver. In man, post-mortem hepatic perfusions carried out by Dock (10) showed a reduction in total hepatic perfusibility in large fatty livers.

The development of a method for estimating hepatic blood flow in man $(11,12)$ provided the means for further investigation into this problem. A direct comparison of the hepatic circulation of normal individuals and alcoholic patients with fatty livers was made possible. Furthermore, the rapid disappearance of fat from the livers of alcoholic patients following a period of therapy $(7,13)$ provided an opportunity to compare the hepatic blood flow in the same individuals before and after clearance of fat had occurred. The present paper reports the results of such a study.

\section{MATERTAL AND METHODS}

The hepatic blood flow was estimated in two groups of male subjects. The first consisted of 17 hospital patients who were conisidered "normal" inasmuch as they exhibited no evidence of cardiovascular, hepatic, biliary or gastrointestinal disease. The second group was made up of 12 alcoholic patients who were selected to include only men with fatty fivers' and without clinical signs of advanced cirrhosis. The following criteria were used for selection: 1) All admitted to a' steady, daily; alcohol consumption, many months in duration, lasting up to the date of admission; 2) All gave histories of dietary deficiency ; 3) Hepatomegaly was present in all cases; 4) None was jaundiced or febrile; 5) Splenomegaly or such evidence of portal hypertension as ascites or collateral veins was not demonstrable in any patient.

Each alcoholic patient was studied as soon after admission as practicable. The study was repeated, following a period of alcohol withdrawal, nutritious diet, and bed rest, when it was felt that the patient had achieved maximum improvement. At that time physical examination and the results of routine liver function studies no longer indicated the presence of liver disease. The time interval between the admission study and the study at "maximum improvement" of the alcoholic patients ranged from 21 to 116 days, the average interval being 44 days.

Essentially, the procedure described by Bradley, Ingelfinger, Bradley, and Curry (11) for estimating hepatic blood flow was followed. The patients were in the resting state, fasting, and had received Nembutal $0.1 \mathrm{gm}$. one hour previously. A cardiac catheter was introduced into a medial antecubital vein and directed, under fluoroscopic vision, through the superior vena cava, right auricle, and inferior vena cava into a right hepatic vein. An infusion of bromsulfalein in isotonic saline (50 to 100 $\mathrm{mgm}$. per $100 \mathrm{ml}$.) was started and a priming dose of approximately $2 \mathrm{mgm}$. per $\mathrm{Kg}$. of bromsulfalein administered. A Graubard-Peterson Flowrator meter was used to maintain a constant infusion rate of $4 \mathrm{ml}$. per min. After an equilibration period of from 30 to 45 minutes, samples were drawn simultaneously from the hepatic vein and a peripheral vein or a brachial artery at intervals of from 7 to 10 minutes. Usually five pairs of specimens were thus obtained.

In addition to hepatic blood flow determinations in eight of the normal and eight of the alcoholic patients, 
blood was drawn from the hepatic vein under anaerobic conditions for determination of oxygen content and calculation of splanchnic oxygen consumption. In these instances, when the collection of blood samples for the estimation of hepatic blood flow was completed, the catheter was withdrawn into the right auricle. Blood was then obtained simultaneously from the auricle and artery during the collection of a four-minute sample of expired air into a Douglas bag for calculation of cardiac output. Plasma volume was determined by the 10-minute Evans Blue Dye technique. Within 24 hours of the time of each hepatic vein catheterization, a needle biopsy of the liver was obtained.

When patients were studied twice, the second procedure duplicated the first in every respect. Every effort was made to replace the catheter in approximately the same area of the liver as in the first procedure.

Serum bromsulfalein levels were determined in duplicate with the Beckman spectrophotometer as described by Myers (12). Duplicate measurements exceeding 5 per cent in variation were discarded. All hemolyzed specimens were discarded. The concentration of bromsulfalein in infusion mixtures was determined similarly. Blood oxygen content was determined by the manometric method of Van Slyke and Neill (14). In the majority of instances duplicate detreminations checked within $0.10 \mathrm{ml}$. per $100 \mathrm{ml}$. and all checked within $0.15 \mathrm{ml}$. per $100 \mathrm{ml}$. Expired air volume was measured with a gasometer and the oxygen and carbon dioxide contents determined with the Scholander micro-gas analyzer (15).

Calculation of the hepatic blood flow with correction for variations in the peripheral bromsulfalein level was carried out according to Bradley, Ingelfinger, Bradley, and Curry (11). Where the rate of change of the peripheral bromsulfalein level exceeded $.0002 \mathrm{mgm}$. per ml. per min. the experiment was discarded.

Liver biopsy specimens were fixed in 10 per cent formalin, sectioned, and stained with hematoxylin and eosin. The sections were examined and the results classified without knowledge of the patient's identity.
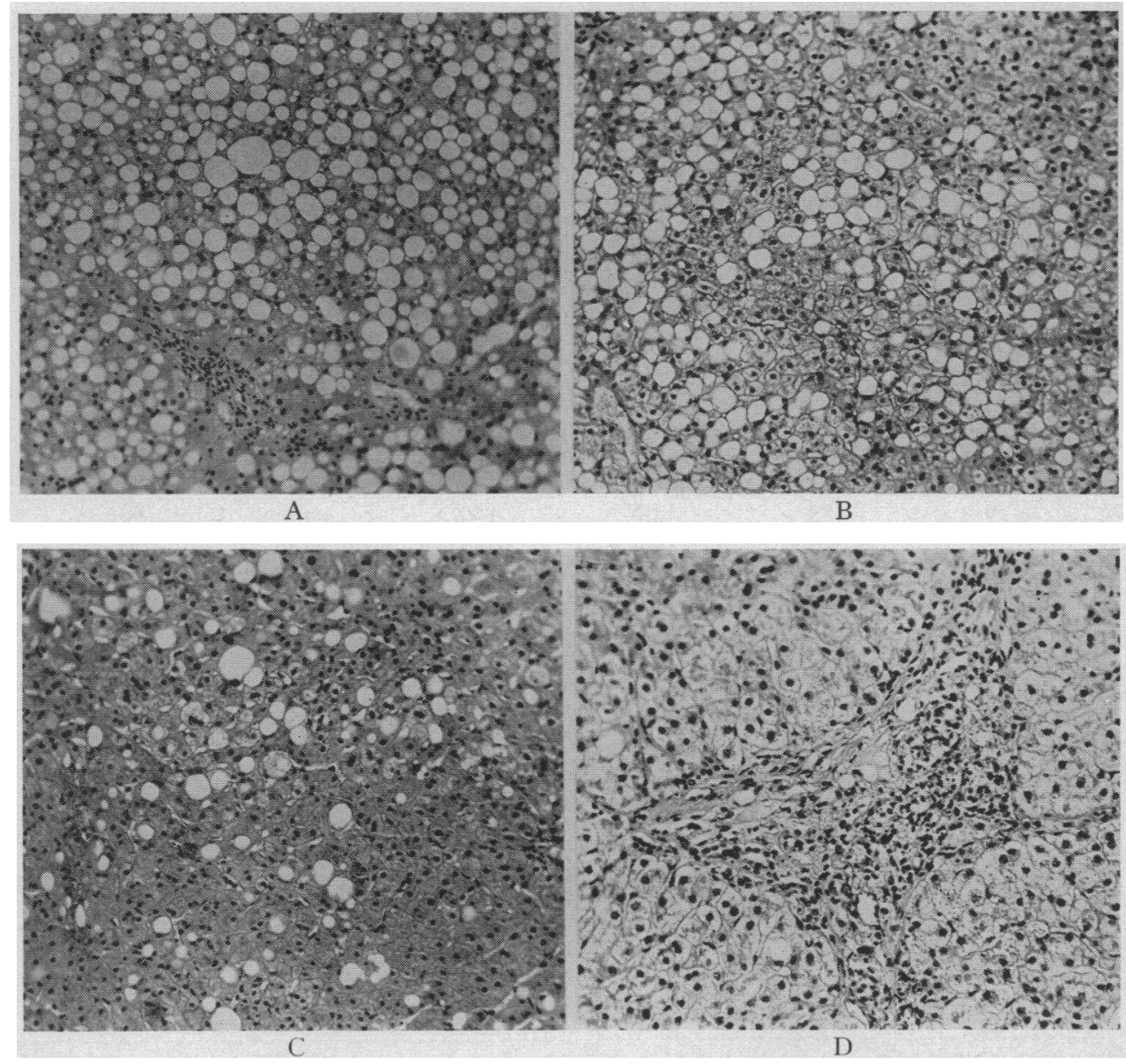

Fig. 1. Liver Biopsies, Showing Fatty Infiltration of Marked (A), Moderate (B) and Mild Degree (C) and Increased Periportal Fibrosis (D) 
TABLE I

Summary of hepatic blood flow observations on 17 normal and 12 alcoholic subjects

\begin{tabular}{|c|c|c|c|c|c|c|c|c|c|}
\hline & \multicolumn{3}{|c|}{$\underset{m l . / m i n . / M^{2}}{\mathrm{EHBF}}$} & \multicolumn{3}{|c|}{$\underset{\text { per cent }}{\mathrm{E}(\mathrm{BSP}) \dagger}$} & \multicolumn{3}{|c|}{$\underset{m l . / \min . / M^{2}}{\mathrm{C}(\mathrm{BSP}) \ddagger}$} \\
\hline & Range & Mean & S.D. & Range & Mean & S.D. & Range & Mean & S.D. \\
\hline $\begin{array}{l}\text { Normal subjects } \\
\text { Alcoholic patients No. } 1 \S \\
\text { Alcoholic patients No. } 2 \|\end{array}$ & $\begin{array}{l}550-1,120 \\
430-1,090 \\
460-930\end{array}$ & $\begin{array}{l}770 \\
650 \\
670\end{array}$ & $\begin{array}{l}154 \\
170 \\
124\end{array}$ & $\begin{array}{l}33.7-82.0 \\
15.9-72.8 \\
39.2-77.4\end{array}$ & $\begin{array}{l}56.9 \\
44.3 \\
58.6\end{array}$ & $\begin{array}{l}12.9 \\
19.6 \\
11.9\end{array}$ & $\begin{array}{r}187-306 \\
44-253 \\
126-318\end{array}$ & $\begin{array}{l}241 \\
154 \\
223\end{array}$ & $\begin{array}{l}38 \\
63 \\
51\end{array}$ \\
\hline
\end{tabular}

* Estimated hepatic blood flow.

† Hepatic bromsulfalein extraction.

\# Hepatic bromsulfalein clearance. $"$

Alcoholic patients studied shortly after admission.

II Same alcoholic patients studied after period of treatment.

\section{RESULTS}

Liver biopsies done in conjunction with the estimation of hepatic blood flow in alcoholic patients shortly after admission revealed fat infiltration of varying severity in all cases. In six cases it was marked, in four it was moderate, and in two it was minimal. Representative sections of these degrees of fat infiltration are illustrated in Figure 1. Biopsies obtained after treatment in the alcoholic patients showed varying degrees of fat clearance in all patients. At the time hepatic blood flow was restudied there was virtually complete disappear- ance of fat from the liver of nine patients and minimal fat infiltration remaining in three patients.

Increased periportal fibrosis was observed in the biopsies obtained from 9 of 12 alcoholic patients. In all these instances the fibrosis was minimal. Reduplication of bile ducts or architectural distortion of the liver was not seen. No fibrosis was found in any one of several biopsies done on each of the remaining three patients.

The data relating to hepatic blood flow are summarized in Table I. Although the mean estimated hepatic blood flow for the group of alcoholic patients shortly after admission is lower than that

TABLE II

Normal subjects

\begin{tabular}{|c|c|c|c|c|c|c|c|}
\hline Subject & $\begin{array}{l}\text { Age } \\
\text { yrs. }\end{array}$ & $\begin{array}{c}\text { Body } \\
\text { surface } \\
\text { area } \\
M^{2} \\
\end{array}$ & $\begin{array}{c}\text { Hema- } \\
\text { tocrit } \\
\mathrm{mm} .\end{array}$ & $\begin{array}{c}\mathrm{P}(\mathrm{BSP}) * \\
\mathrm{mgm.} / 100 \mathrm{ml} .\end{array}$ & $\begin{array}{l}\mathrm{E}(\mathrm{BSP}) \dagger \\
\text { per cent }\end{array}$ & $\underset{m l . / m i n . / M^{2}}{\mathrm{C}(\mathrm{BSP}) \ddagger}$ & $\underset{m l . / m i n . / M^{2}}{\mathrm{EHBF}}$ \\
\hline $\begin{array}{l}\text { MAT } \\
\text { SAN } \\
\text { BUR } \\
\text { FOL } \\
\text { KLO } \\
\text { CLA } \\
\text { ORI } \\
\text { RUT } \\
\text { HUL } \\
\text { WAL } \\
\text { GRE } \\
\text { KEL } \\
\text { DUN } \\
\text { MEI } \\
\text { COH } \\
\text { SAL } \\
\text { BRO }\end{array}$ & $\begin{array}{l}29 \\
31 \\
37 \\
42 \\
37 \\
51 \\
22 \\
29 \\
42 \\
27 \\
45 \\
35 \\
32 \\
29 \\
25 \\
27 \\
38\end{array}$ & $\begin{array}{l}1.82 \\
1.86 \\
1.78 \\
1.73 \\
1.73 \\
1.96 \\
1.79 \\
1.75 \\
1.86 \\
1.63 \\
1.68 \\
1.77 \\
1.76 \\
1.73 \\
1.81 \\
1.86 \\
1.61\end{array}$ & $\begin{array}{l}42.0 \\
48.0 \\
45.0 \\
44.0 \\
40.0 \\
38.0 \\
42.5 \\
47.0 \\
43.5 \\
37.5 \\
37.5 \\
44.0 \\
46.5 \\
39.0 \\
44.0 \\
42.0 \\
37.0\end{array}$ & $\begin{array}{l}0.87 \\
0.82 \\
1.05 \\
0.87 \\
0.86 \\
1.02 \\
0.90 \\
0.66 \\
0.66 \\
1.21 \\
0.86 \\
1.01 \\
0.98 \\
0.69 \\
0.77 \\
0.65 \\
0.77\end{array}$ & $\begin{array}{l}41.4 \\
59.8 \\
68.6 \\
59.8 \\
53.5 \\
41.7 \\
60.0 \\
66.6 \\
82.0 \\
44.6 \\
33.7 \\
46.5 \\
56.1 \\
66.7 \\
66.4 \\
73.8 \\
46.8\end{array}$ & $\begin{array}{l}266 \\
212 \\
206 \\
212 \\
192 \\
209 \\
253 \\
286 \\
306 \\
187 \\
251 \\
248 \\
211 \\
286 \\
294 \\
203 \\
275\end{array}$ & $\begin{array}{r}1.120 \\
680 \\
550 \\
670 \\
590 \\
760 \\
720 \\
800 \\
630 \\
670 \\
1,110 \\
890 \\
720 \\
700 \\
800 \\
750 \\
880\end{array}$ \\
\hline $\begin{array}{l}\text { Mean } \\
\text { S.D. } \\
\text { S.E. }\end{array}$ & & & & $\begin{array}{l}0.86 \\
0.15 \\
0.04\end{array}$ & $\begin{array}{r}56.9 \\
12.9 \\
3.1\end{array}$ & $\begin{array}{r}241 \\
38 \\
4\end{array}$ & $\begin{array}{r}770 \\
154 \\
37\end{array}$ \\
\hline
\end{tabular}

* Peripheral bromsulfalein concentration.

+ Bromsulfalein extraction.

¥ Bromsulfalein clearance.

$\$$ Estimated hepatic blood flow. 
TABLE III

Alcoholic subjects shortly after admission *

\begin{tabular}{|c|c|c|c|c|c|c|c|c|c|}
\hline Subject & $\begin{array}{l}\text { Age } \\
\text { yrs. }\end{array}$ & $\begin{array}{c}\text { Body } \\
\text { surface } \\
\text { area } \\
\boldsymbol{M}^{\mathbf{2}}\end{array}$ & $\begin{array}{c}\text { Hema- } \\
\text { tocrit } \\
\text { mm. }\end{array}$ & $\underset{m g m . / 100}{P(B S P}$. & $\begin{array}{l}\text { E(BSP) } \\
\text { per cent }\end{array}$ & $\underset{m l . / m i x . / M^{2}}{C(B S P)}$ & $\underset{m l . / m i n . / M^{2}}{\text { EHBF }}$ & $\underset{\text { fat }}{\text { Hepatic }}$ & $\begin{array}{r}\text { Hepatic } \\
\text { fibrosis }\end{array}$ \\
\hline $\begin{array}{l}\text { COU } \\
\text { PLE } \\
\text { MLA } \\
\text { GRE } \\
\text { MOO } \\
\text { DER } \\
\text { COG } \\
\text { DOW } \\
\text { CIO } \\
\text { MTI } \\
\text { SCH } \\
\text { MIN }\end{array}$ & $\begin{array}{l}44 \\
40 \\
62 \\
35 \\
35 \\
34 \\
45 \\
46 \\
39 \\
52 \\
51 \\
44\end{array}$ & $\begin{array}{l}1.92 \\
1.82 \\
1.66 \\
1.67 \\
1.58 \\
1.65 \\
1.95 \\
1.82 \\
1.84 \\
2.02 \\
1.66 \\
1.49\end{array}$ & $\begin{array}{l}49.0 \\
40.0 \\
37.5 \\
38.0 \\
34.0 \\
44.0 \\
43.5 \\
44.0 \\
37.0 \\
52.0 \\
38.5 \\
45.0\end{array}$ & $\begin{array}{l}2.29 \\
2.76 \\
1.19 \\
0.72 \\
1.32 \\
1.34 \\
1.25 \\
0.55 \\
0.93 \\
1.34 \\
0.62 \\
0.67\end{array}$ & $\begin{array}{l}19.2 \\
16.3 \\
48.7 \\
51.4 \\
15.9 \\
30.6 \\
45.6 \\
67.3 \\
45.2 \\
45.5 \\
72.6 \\
72.8\end{array}$ & $\begin{array}{r}73 \\
44 \\
129 \\
192 \\
120 \\
130 \\
155 \\
253 \\
200 \\
113 \\
252 \\
182\end{array}$ & $\begin{array}{r}730 \\
470 \\
430 \\
610 \\
1,090 \\
780 \\
620 \\
670 \\
720 \\
500 \\
580 \\
540\end{array}$ & $\begin{array}{l}\text { mar } \\
\text { mar } \\
\text { mar } \\
\text { mod } \\
\text { mar } \\
\text { mod } \\
\operatorname{mar} \\
\bmod \\
\bmod \\
\operatorname{mar} \\
\min \\
\min \end{array}$ & $\begin{array}{r}\mathbf{X} \\
\mathbf{X} \\
\mathbf{0} \\
\mathbf{X} \\
\mathbf{X} \\
\mathbf{0} \\
\mathbf{X} \\
\mathbf{X} \\
\mathbf{X} \\
\mathbf{X} \\
\mathbf{X} \\
\mathbf{0}\end{array}$ \\
\hline $\begin{array}{l}\text { Mean } \\
\text { S.D. } \\
\text { S.E. }\end{array}$ & & & & $\begin{array}{l}1.25 \\
0.77 \\
0.23\end{array}$ & $\begin{array}{r}44.3 \\
19.6 \\
5.7\end{array}$ & $\begin{array}{r}154 \\
63 \\
18\end{array}$ & $\begin{array}{r}650 \\
170 \\
80\end{array}$ & & \\
\hline
\end{tabular}

* See Table II for explanation of abbreviations.

$t$ mar - Marked fat infiltration.

mod-Moderate fat infiltration.

min-Minimal fat infiltration.

for the normal subjects (Tables II and III), the difference between the two means is not statistically significant (relative deviate, dev/S.E. $=1.9$ ). When the hepatic blood flow in the alcoholic patients before and after the treatment period is compared (Tables III and IV), it may be seen that in three it decreased and in nine it increased. In six of the latter, however, the increase was less than 10 per cent. The mean hepatic blood flow after treatment was almost identical to that prior to treatment.
The mean hepatic extraction of bromsulfalein for the alcoholic group on admission was lower than that for the control group. The difference is not statistically significant (dev./S.E. $=1.9$ ). Following the treatment period, the mean hepatic bromsulfalein extraction for the alcoholic patients was simliar to that for the control group. The difference between the mean bromsulfalein clearance for alcoholic patients, when first studied, and that for the control group is significant (dev./S.E. $=4.3$ ). The mean bromsulfalein clearance for

TABLE IV

Alcoholic subjects after treatment period *

\begin{tabular}{|c|c|c|c|c|c|c|c|c|}
\hline Subject & $\begin{array}{c}\text { Body } \\
\text { surface } \\
\text { area } \\
\boldsymbol{M}^{2}\end{array}$ & $\begin{array}{c}\text { Hema- } \\
\text { tocrit } \\
\text { mm. }\end{array}$ & 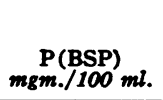 & $\begin{array}{l}\text { E(BSP) } \\
\text { per cent }\end{array}$ & $\underset{m l . / \min .}{\mathrm{C}(\mathrm{BSP})})_{M^{2}}$ & $\underset{m l . / m i n . / M^{2}}{\text { EHBF }}$ & $\begin{array}{c}\text { Hepatic } \\
\text { fat }\end{array}$ & $\begin{array}{r}\text { Hepatic } \\
\text { fibrosis }\end{array}$ \\
\hline $\begin{array}{l}\text { COU } \\
\text { PLE } \\
\text { MLA } \\
\text { GRE } \\
\text { MOO } \\
\text { DER } \\
\text { COG } \\
\text { DOW } \\
\text { CIO } \\
\text { MTI } \\
\text { SCH } \\
\text { MIN }\end{array}$ & $\begin{array}{l}1.97 \\
1.82 \\
1.77 \\
1.71 \\
1.66 \\
1.70 \\
1.98 \\
1.87 \\
1.86 \\
1.98 \\
1.75 \\
1.59\end{array}$ & $\begin{array}{l}43.0 \\
44.5 \\
40.0 \\
48.0 \\
38.5 \\
39.0 \\
46.0 \\
42.5 \\
39.5 \\
47.0 \\
40.5 \\
40.0\end{array}$ & $\begin{array}{l}1.08 \\
1.38 \\
0.95 \\
1.01 \\
0.74 \\
0.80 \\
0.81 \\
0.63 \\
0.90 \\
0.73 \\
0.96 \\
0.53\end{array}$ & $\begin{array}{l}65.7 \\
45.7 \\
58.9 \\
55.4 \\
39.2 \\
57.5 \\
69.1 \\
73.0 \\
43.3 \\
68.5 \\
49.0 \\
77.4\end{array}$ & $\begin{array}{l}172 \\
126 \\
184 \\
190 \\
230 \\
239 \\
236 \\
299 \\
214 \\
257 \\
210 \\
318\end{array}$ & $\begin{array}{l}460 \\
500 \\
530 \\
670 \\
930 \\
660 \\
630 \\
730 \\
790 \\
710 \\
720 \\
700\end{array}$ & $\begin{array}{c}\min . \\
\min . \\
0 \\
\min . \\
0 \\
0 \\
0 \\
0 \\
0 \\
0 \\
0 \\
0\end{array}$ & $\begin{array}{l}\mathbf{X} \\
\mathbf{X} \\
\mathbf{0} \\
\mathbf{X} \\
\mathbf{X} \\
\mathbf{0} \\
\mathbf{X} \\
\mathbf{X} \\
\mathbf{X} \\
\mathbf{X} \\
\mathbf{X} \\
\mathbf{0}\end{array}$ \\
\hline $\begin{array}{l}\text { Mean } \\
\text { S.D. } \\
\text { S.E. }\end{array}$ & & & $\begin{array}{l}0.88 \\
0.31 \\
0.09\end{array}$ & $\begin{array}{r}58.6 \\
11.9 \\
3.4\end{array}$ & $\begin{array}{r}223 \\
51 \\
15\end{array}$ & $\begin{array}{r}670 \\
124 \\
36\end{array}$ & & \\
\hline
\end{tabular}

* See Table II for explanation of abbreviations. 
TABLE V

Normal subjects

\begin{tabular}{|c|c|c|c|c|c|c|c|}
\hline Subject & $\begin{array}{c}\text { Oxygen } \\
\text { consumption } \\
\text { ml./min./M: }\end{array}$ & $\begin{array}{c}\text { Candiac } \\
\text { index } \\
L . / \text { min. }^{\prime} / M^{2}\end{array}$ & $\begin{array}{c}\text { Splanchnic } \\
\text { oxygen } \\
\text { congumption } \\
\text { ml./mint } \sqrt{M^{2}}\end{array}$ & $\begin{array}{c}\text { Splanchnic } \mathrm{O}_{2} \\
\text { consumption } \\
\text { as \% of total } \\
\mathrm{O}_{2} \text { consumption } \\
\text { per cent }\end{array}$ & $\begin{array}{c}\text { Hepatic } \\
\text { vein } \\
\text { oxygen } \\
\text { content } \\
\text { ml. } / 100 \mathrm{ml} .\end{array}$ & $\begin{array}{c}\text { Hepatic } \\
\text { arterio- } \\
\text { venous } \\
\text { oxygen } \\
\text { difference } \\
\text { ml. } / 100 \mathrm{ml} .\end{array}$ & $\begin{array}{l}\text { Hepatic } \\
\text { vein } \\
\text { oxvean } \\
\text { eaturation } \\
\text { per cems }\end{array}$ \\
\hline $\begin{array}{l}\text { WAL } \\
\text { GRE } \\
\text { KEL } \\
\text { DUN } \\
\text { MEI } \\
\text { COH } \\
\text { SAL } \\
\text { BRO }\end{array}$ & $\begin{array}{l}116.7 \\
158.6 \\
151.5 \\
134.0 \\
146.3 \\
147.1 \\
148.7 \\
131.6\end{array}$ & $\begin{array}{l}3.3 \\
4.4 \\
3.9 \\
3.6 \\
4.3 \\
3.5 \\
4.0 \\
3.5\end{array}$ & $\begin{array}{l}32.5 \\
32.9 \\
26.9 \\
21.8 \\
21.0 \\
27.7 \\
24.9 \\
25.7\end{array}$ & $\begin{array}{l}27.8 \\
20.7 \\
17.8 \\
16.3 \\
14.4 \\
18.8 \\
18.3 \\
17.3\end{array}$ & $\begin{array}{l}10.7 \\
11.3 \\
16.7 \\
16.0 \\
13.4 \\
14.6 \\
13.5 \\
13.0\end{array}$ & $\begin{array}{l}4.9 \\
3.4 \\
3.0 \\
3.0 \\
3.0 \\
3.5 \\
2.8 \\
3.4\end{array}$ & $\begin{array}{l}62.1 \\
71.0 \\
77.9 \\
77.4 \\
71.8 \\
75.0 \\
74.6 \\
73.2\end{array}$ \\
\hline $\begin{array}{l}\text { Mean } \\
\text { S.D. } \\
\text { S.E. }\end{array}$ & $\begin{array}{r}141.8 \\
12.8 \\
4.5\end{array}$ & $\begin{array}{l}3.8 \\
0.4 \\
0.1\end{array}$ & $\begin{array}{r}26.7 \\
4.3 \\
1.5\end{array}$ & $\begin{array}{r}18.9 \\
3.8 \\
1.3\end{array}$ & & $\begin{array}{l}3.4 \\
0.6 \\
0.2\end{array}$ & $\begin{array}{r}72.9 \\
4.8 \\
1.7\end{array}$ \\
\hline
\end{tabular}

Alcoholic patients shortly after admission

\begin{tabular}{|c|c|c|c|c|c|c|c|c|}
\hline Subject & $\begin{array}{c}\text { Oxygen } \\
\text { consumption } \\
m l . / m i n . / M^{2}\end{array}$ & $\begin{array}{c}\text { Cardiac } \\
\text { index } \\
L . / \operatorname{min.} / M^{2}\end{array}$ & $\begin{array}{c}\text { Splanchnic } \\
\text { oxygen } \\
\text { consumption } \\
\text { ml./min./Mº }\end{array}$ & $\begin{array}{c}\text { Splanchnic } \mathrm{O}_{2} \\
\text { consumption } \\
\text { as \% of total } \\
\mathrm{O}_{2} \text { consumption } \\
\text { per cent }\end{array}$ & $\begin{array}{c}\text { Hepatic } \\
\text { vein } \\
\text { oxygen } \\
\text { content } \\
\text { ml. } / 100 \mathrm{ml} .\end{array}$ & $\begin{array}{c}\text { Hepatic } \\
\text { arterio- } \\
\text { venous } \\
\text { oxygen } \\
\text { difiference } \\
\text { ml./100 ml. }\end{array}$ & $\begin{array}{c}\text { Hepatic } \\
\text { vein } \\
\text { orygen } \\
\text { saturation } \\
\text { per cent }\end{array}$ & $\begin{array}{c}\text { Hospital } \\
\text { day test } \\
\text { performed }\end{array}$ \\
\hline $\begin{array}{l}\text { MOO } \\
\text { DER } \\
\text { COG } \\
\text { DOW } \\
\text { CIO } \\
\text { MTI } \\
\text { SCH } \\
\text { MIN }\end{array}$ & $\begin{array}{l}171.1 \\
145.3 \\
177.9 \\
167.8 \\
168.1 \\
170.8 \\
174.0\end{array}$ & $\begin{array}{l}3.6 \\
3.3 \\
2.9 \\
3.6 \\
2.8 \\
4.2 \\
3.6\end{array}$ & $\begin{array}{l}75.2 \\
62.6 \\
38.1 \\
61.6 \\
38.2 \\
32.7 \\
36.8 \\
35.8\end{array}$ & $\begin{array}{l}36.6 \\
26.2 \\
34.6 \\
22.8 \\
19.5 \\
21.5 \\
20.6\end{array}$ & \begin{tabular}{r|}
9.0 \\
8.4 \\
11.9 \\
8.1 \\
10.4 \\
12.4 \\
7.8 \\
10.2
\end{tabular} & $\begin{aligned} & 6.9 \\
& 8.0 \\
& 6.1 \\
& 9.2 \\
& 5.3 \\
& 6.5 \\
& 6.3 \\
& 6.6\end{aligned}$ & $\begin{array}{r}58.4 \\
41.0 \\
63.9 \\
44.5 \\
61.1 \\
57.1 \\
48.7 \\
52.2\end{array}$ & $\begin{array}{l}5 \\
1 \\
4 \\
2 \\
6 \\
4 \\
1 \\
2\end{array}$ \\
\hline $\begin{array}{l}\text { Mean } \\
\text { S.D. } \\
\text { S.E. }\end{array}$ & $\begin{array}{r}167.9 \\
9.8 \\
3.7\end{array}$ & $\begin{array}{l}3.4 \\
0.4 \\
0.2\end{array}$ & $\begin{array}{r}47.6 \\
15.2 \\
5.5\end{array}$ & $\begin{array}{r}26.0 \\
6.4 \\
2.4\end{array}$ & & $\begin{array}{l}6.9 \\
1.2 \\
0.4\end{array}$ & $\begin{array}{r}53.4 \\
7.6 \\
2.7\end{array}$ & \\
\hline \multicolumn{9}{|c|}{ Alcoholic patients after treatment } \\
\hline $\begin{array}{l}\text { MOO } \\
\text { DER } \\
\text { COG } \\
\text { DOW } \\
\text { CIO } \\
\text { MTI } \\
\text { SCH } \\
\text { MIN }\end{array}$ & $\begin{array}{l}164.3 \\
122.5 \\
183.6 \\
158.5 \\
119.5 \\
146.3 \\
144.3\end{array}$ & $\begin{array}{l}4.2 \\
2.9 \\
5.3 \\
3.9 \\
3.6 \\
4.7 \\
3.8\end{array}$ & $\begin{array}{l}40.9 \\
25.5 \\
25.5 \\
34.3 \\
32.3 \\
32.0 \\
26.0 \\
26.1\end{array}$ & $\begin{array}{l}15.5 \\
20.8 \\
18.7 \\
20.4 \\
26.8 \\
17.8 \\
18.0\end{array}$ & $\begin{array}{l}11.7 \\
11.6 \\
14.3 \\
12.0 \\
11.3 \\
12.5 \\
11.3 \\
13.7\end{array}$ & $\begin{array}{l}4.4 \\
3.9 \\
4.1 \\
4.7 \\
4.1 \\
4.5 \\
3.6 \\
3.7\end{array}$ & $\begin{array}{l}67.8 \\
67.4 \\
74.9 \\
65.9 \\
67.7 \\
60.8 \\
69.9 \\
74.8\end{array}$ & $\begin{array}{r}37 \\
29 \\
36 \\
50 \\
50 \\
120 \\
55 \\
38\end{array}$ \\
\hline $\begin{array}{l}\text { Mean } \\
\text { S.D. } \\
\text { S.E. }\end{array}$ & $\begin{array}{r}148.4 \\
21.1 \\
8.0\end{array}$ & $\begin{array}{l}4.1 \\
0.7 \\
0.3\end{array}$ & $\begin{array}{r}30.3 \\
5.1 \\
1.8\end{array}$ & $\begin{array}{r}19.7 \\
3.3 \\
1.3\end{array}$ & & $\begin{array}{l}4.1 \\
0.4 \\
0.1\end{array}$ & $\begin{array}{r}68.6 \\
4.4 \\
1.5\end{array}$ & \\
\hline
\end{tabular}

alcoholic patients after the treatment period was not significantly different from the control mean $($ dev./S.E. $=1.0)$.

Table V contains the above-mentioned, additional data on eight normal and eight alcoholic subjects. The calculated oxygen uptake in the splanchnic area in the normal subjects ranged from 21.0 to $32.9 \mathrm{ml}$. per min.'per sq. M., the mean being $26.7 \pm 4.3 \mathrm{ml}$. In the alcoholic patients, when first studied, the splanchnic oxygen uptake ranged from 32.7 to $75.2 \mathrm{ml}$. per min. per sq. M., the mean being $47.6 \pm 15.2 \mathrm{ml}$. Following treatment, the splanchnic oxygen uptake for these alcoholic patients ranged from 25.5 to $40.9 \mathrm{ml}$. per min. per sq. M., the mean $(30.3 \pm 5.1 \mathrm{ml}$.) having returned to a level only slightly higher than the control mean.

The average total oxygen consumption in the alcoholic patients before treatment was $167.9 \pm$ 
$9.8 \mathrm{ml}$. per sq. M. per min., which was higher than the average in the same patients following treatment (148.4 $\pm 21.1 \mathrm{ml}$. per sq. M. per min.). : The difference in these averages is $19.5 \mathrm{ml}$., which matches closely the difference in averages of the splanchnic oxygen consumption before and after treatment Th splanchnic oxygn consumption, when expressed as a percentage of the corresponding total oxygen consumption, was 27 per cent before treatment and 20 per cent after treatment. In the normal individuals the splanchnic oxygen consumption comprised 19 per cent of the total oxygen consumption.

The mean hepatic arterio-venous oxygen difference and mean hepatic venous oxygen saturation for the normal group were $3.4 \pm 0.6 \mathrm{ml}$. per 100 $\mathrm{ml}$. and $72.9 \pm 4.8$ per cent, respectively. In the alcoholic patients, the average hepatic arteriovenous oxygen difference was $6.9 \pm 1.2 \mathrm{ml}$. per $100 \mathrm{ml}$., shortly after admission and $4.1 \pm 0.4 \mathrm{ml}$. per $100 \mathrm{ml}$., after the treatment period. The average hepatic venous oxygen saturation in the alcoholic individuals was $53.4 \pm 7.6$ per cent before treatment and $68.7 \pm 4.4$ per cent after treatment.

\section{DISCUSSION}

The results of hepatic blood flow measurements indicate that fat infiltration in the liver of alcoholic patients does not result in an impairment of the total hepatic blood circulation. The fact that in the group of alcoholic patients, before and after fat disappearance, the mean hepatic blood flow was somewhat lower than normal is not surprising inasmuch as the liver biopsies of the majority of these patients showed increased fibrosis. Bradley, Ingelfinger, and Bradley (16) reported a significant decrease in the hepatic blood flow of individuals with advanced cirrhosis. Their patients exhibited clinical evidence of portal hypertension and an average hepatic bromsulfalein extraction significantly lower than normal. The alcoholic patients in the present study differed from those of Bradley, Inglefinger, and Bradley. Following a period of treatment, they displayed no clinical signs of liver disease and their averages for bromsulfalein extraction and bromsulfalein clearance were quite similar to the normal group. These findings confirm the impression, obtained histologicaly, that the cirrhosis was minimal if present.
This may explain the lack of a statistically significant difference in mean hepatic blood flow between the normal and alcoholic subjects although it is possible that if these studies were extended to larger groups this difference might then become significant.

The increased splanchnic oxygen uptake in the alcoholic patients shortly after admission is of considerable interest. Although it is not possible to determine whether or not this increase in oxygen consumption occurred in the liver, there is no reason to account for it elsewhere in the splanchnic area. Splanchnic oxygen consumption is the calculated product of splanchnic blood flow and the hepatic arterio-verious oxygen difference. Since, in these studies, the average splanchnic blood flow was lower than normal, the increase in splanchnic oxygen consumption was accounted for solely in the hepatic arterio-venous difference. The average value for this difference was 65 per cent greater in the initial test of the alcoholic patients than in the test following the treatment period and 100 per cent greater than the average value for the normal subjects.

The reduction which occurred in the hepatic arterio-venous oxygen difference following the treatment period was more striking in some patients than in others. This did not appear to be related to the severity of fat infiltration, but rather to the time interval between admission and the initial hepatic vein catheterization. Thus; the greatest percentage change in hepatic arterio-venous oxygen difference occurred in the four patients whose initial test was done on the first and second days after admission. In these patients the initial liver biopsy showed moderate fatty infiltration in two and mild fatty infiltration in two. The least percentage change in hepatic arterio-venous oxygen difference occurred in the four patients whose initial study was done on the fourth, fifth, and sixth days after admission. Yet the initial liver biopsies in these patients showed fatty infiltration which was moderate in one and marked in three. This was also true for the values of hepatic venous oxygen saturation. The patients studied on the first and second days after admission showed the lowest saturations. Because none of the alcoholic patients was seriously intoxicated at the time of admission, it seems unlikely that these findings 
are related to alcohol oxidation in the liver 24 to 48 hours after alcohol withdrawal. Moreover, elevated splanchnic oxygen uptakes four to six days after the day of alcohol withdrawal makes this possibility even less likely.

It would appear, therefore, that in the fatty livers of alcoholic patients, as a result of increased splanchnic oxygen uptake and subnormal hepatic blood flow, the centrolobular hepatic cells are perfused by blood with oxygen tensions which are lower than normal. Myers and Hickam have shown that centrolobular anoxia exists in heart failure (17) and thyrotoxicosis (18) and they have considered the possible relation of this finding to the centrolobular necrosis which may be found in either of these diseases. Centrolobular necrosis is not a prominent feature in the histological picture of alcoholic fatty liver. However, the indication of existing centrolobular anoxia in this disease in part supports the hypothesis advanced by Himsworth (8) that anoxia produces slow atrophy of centrolobular cells and the eventual development of hepatic fibrosis.

\section{SUM MARY}

1. The presence of fatty infiltration of the liver in alcoholic patients does not appear to alter hepatic blood flow as estimated by the bromsulfalein technique. In 12 such patients with histologically demonstrated fatty livers, the mean hepatic blood flow was slightly, although not significantly, lower than that for 17 normal individuals. Moreover, after histological demonstration of fat disappearance in the same alcoholic patients, the mean hepatic blood flow was the same.

2. In eight of the alcoholic patients and eight of the normal individuals, the hepatic arterio-venous oxygen difference was determined. In the alcoholic patients prior to treatment, increases in the splanchnic oxygen consumption and hepatic arterio-venous oxygen difference were found. These were associated with lowered values for hepatic venous oxygen saturation. The possibility that this anoxia is of significance as a contributing factor to the damage of centrolobular hepatic cells is raised.

3. Before treatment the alcoholic patients showed a decreased ability to excrete bromsulfalein as evidenced by lowered bromsulfalein extraction and bromsulfalein clearance. These values returned to normal following the treatment period. There was a corresponding return of the hepatic arterio-venous oxygen difference to near normal values.

\section{ACKNOWLEDGMENT}

The authors are grateful to Mr. Paul Glass for his technical assistance.

\section{REFERENCES}

1. Spellberg, M. A., Keeton, R. W., and Ginsberg, R., Dietary production of hepatic cirrhosis in rabbits with an analysis of factors involved. Arch. Path., 1942, 33, 204.

2. Chaikoff, I. L., Eichorn, K. B., Connor, C. L., and Entenman, C., The production of cirrhosis in the liver of the normal dog by prolonged feeding of a high-fat diet. Am. J. Path., 1943, 19, 9.

3. Himsworth, H. P., and Glynn, L. E., Massive hepatic necrosis and diffuse hepatic fibrosis (acute yellow atrophy and portal cirrhosis): their production by means of diet. Clin. Sc., 1944, 5, 93.

4. Connor, C. L., Fatty infiltration of the liver and the development of cirrhosis in diabetes and chronic alcoholism. Am. J. Path., 1938, 14, 347.

5. Buck, R. E., Observations on fatty alcoholic liver: The use of interval needle biopsy and liver function tests. J. Lab. \& Clin. Med., 1948, 33, 555.

6. Sanes, S., Bahn, R. C., Chapple, W. H. C., and Chasin, N., Needle biopsy of the liver in alcoholic patients. New York State J. Med., 1949, 49, 2677.

7. Seife, M., Kessler, B. J., and Lisa, J. R., Clinical, functional and needle biopsy study of the liver in alcoholism. Arch. Int. Med., 1950, 86, 658.

8. Himsworth, H. P., Lectures on the liver and its diseases, 2nd ed., Cambridge, Harvard University Press, 1950.

9. Hartroft, W. S., The Locus of the Beginning of Dietary Cirrhosis. Transactions of the Eighth Conference on Liver Injury, 1949, New York, Josiah Macy, Jr. Foundation, 1950, p. 126.

10. Dock, W., The rôle of increased hepatic arterial flow in the portal hypertension of cirrhosis. Tr. A. Am. Physicians, 1942, 57, 302.

11. Bradley, S. E., Ingelfinger, F. J., Bradley, G. P., and Curry, J. J., The estimation of hepatic blood flow in man. J. Clin. Invest., 1945, 24, 890.

12. Myers, J. D., The hepatic blood flow and splanchnic oxygen consumption of man-their estimation from urea production or bromsulphalein excretion during catheterization of the hepatic veins. J. Clin. Invest., 1947, 26, 1130.

13. Klatskin, G., and Yesner, R., Factors in the treatment of Laennec's cirrhosis. I. Clinical and histological changes observed during a period of bed-rest, al- 
cohol withdrawal, and a minimal basic diet. J. Clin. Invest., 1949, 28, 723.

14. Van Slyke, D. D., and Neill, J. M., The determination of gases in blood and other solutions by vacuum extraction and manometric measurements. I. J. Biol. Chem., 1924, 61, 523.

15. Scholander, P. F., Analyzer for accurate estimation of respiratory gases in one-half cubic centimeter samples. J. Biol. Chem., 1947, 167, 235.

16. Bradley, S. E., Ingelfinger, F. J., and Bradley, G. P.,
Hepatic circulation in cirrhosis of the liver. Circulation, 1952, 5, 419.

17. Myers, J. D., and Hickam, J. B., An estimation of the hepatic blood flow and splanchnic oxygen consumption in heart failure. J. Clin. Invest., 1948, 27, 620 .

18. Myers, J. D., Brannon, E. S., and Holland, B. C., A correlative study of the cardiac output and the hepatic circulation in hyperthyroidism. J. Clin. Invest., 1950, 29, 1069. 